\title{
Impact of Women Circumcision on Mental Health
}

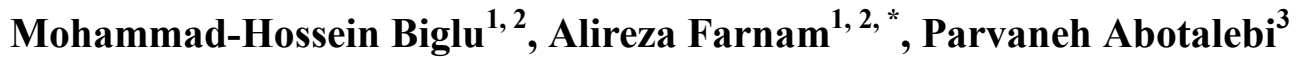 \\ ${ }^{1}$ Department of Clinical Psychology, Tabriz Branch, Islamic Azad University, Tabriz, Iran \\ ${ }^{2}$ Research Center of Psychiatry and Behavioral Sciences, Tabriz University of Medical Sciences, Tabriz, Iran \\ ${ }^{3}$ Tabriz Health Services Management Research Center, Tabriz University of Medical Sciences, Tabriz, Iran \\ Email address: \\ Mh_biglu@yahoo.com (Mohammad-Hossein B.), alirezafarnam@yahoo.com (Farnam A.) \\ ${ }^{*}$ Corresponding author
}

\section{To cite this article:}

Mohammad-Hossein Biglu, Alireza Farnam, Parvaneh Abotalebi. Impact of Women Circumcision on Mental Health. International Journal of Psychological and Brain Sciences. Vol. 2, No. 4, 2017, pp. 100-105. doi: 10.11648/j.ijpbs.20170204.13

Received: May 14, 2017; Accepted: May 24, 2017; Published: July 10, 2017

\begin{abstract}
Female genital mutilation / cutting is a damaging traditional procedure, that affects the psychosomatic wellbeing of women and girls all over the world. It has short-term and long-term of psychological, sexual and physiological effects on women. The objective of current study was to measure the mental health of circumcised women and compare them with noncircumcised women in Kurdistan province of Iran. A total number of 208 married women (104 circumcised-women and 104 non-circumcised-women) those who referred to the healthcare centers for vaccination, midwifery, or family planning services in Kurdistan province of Iran, were selected as the population of study. General Health Questionnaire (GHQ-28) was administered among the participants for data gathering. Gathered Data was analyzed using the soft-ware package of SPSS version 23 by utilizing independent t-test. P-value of less than 0.05 was considered as statistically significant. The findings indicated that there was a major difference in the term of mental well-being between two groups of circumcised and noncircumcised women. The study concluded that circumcised women lose the pleasure of their life as a consequence of female genital mutilation/ cutting. Awareness about mental and psychical status of circumcised women could help them to be prevented from $\mathrm{FGM} / \mathrm{C}$ procedures.
\end{abstract}

Keywords: Genital Mutilation, Genital Cutting, Mental Health, Psychological Consequence, Women

\section{Introduction}

The term of female genital mutilation / cutting (FGM/C), or female circumcision explains the procedures that lead to remove total or partial of external female genital organ for non-medical purposes [1].

Due to the undesirable effects of FGM/C on women and girls' mental well-being, the women's health organizations, international children's rights groups, international human rights, and many nongovernmental organizations have condemned it [2]. Although the international laws and activities are attempting to abandon all types of FGM/C throughout the world, but it is still a major problem of women in many regions and countries. According to the estimations, approximately 130-140 million women and girls have undergone to the $\mathrm{FGM} / \mathrm{C}$ procedures so far [3]. The kind of $\mathrm{FGM} / \mathrm{C}$ varies from country to country, and even within different groups in the same country. In general, the $\mathrm{FGM} / \mathrm{C}$ is classified in four types:
- Type $I$ is the removal of the entire or partial of clitoris (clitoridectomy);

- Type II is the removal of clitoris with total or partial of the minora labia.

- Type III is the removal of all or partial of the external genitalia and stitching the vaginal opening that also called infibulation or suturing.

- Type IV is called heterogeneous type, including incising, pricking, or piercing the external genitalia, cutting the clitoris and/or labia, cauterization and burning the clitoris and neighboring tissue that is performed for narrowing or tightening the vaginal [4].

The Ministry of Health and Medical Education of Iran does not support any kind of FGM/C; therefore, the health professionals (e.g. doctors, nurses, midwives) did not receive any education about FGM/C. It is generally supported by society among Sunni-Muslims in some province of Iran (e. g. 
Kurdistan, Hormozgan, Ilam, Kermanshah, West-Azerbaijan, and Sistan-Baluchestan). To the knowledge and observation of research team the procedures are done without using anesthetics or antiseptics drugs and under unhygienic conditions by local circumcisers in the country. The circumcisers use local herbs, the ash of burned cloths, which they mix with animal-butter for treating the wounds. The FGM/C does not have any health advantages for girls; it also exposes the circumcised women and girls towards excessive risk of suffering from negative psychosomatic consequences. The procedure has immediate and/or longitudinal complications. The immediate problems are excessive bleeding at the time of doing the procedure, problematic urination, shock through the procedure, genital ulceration and wrong adjacent of tissue $[5,6]$. Further problems such as: Fibrosis, keloids, and clitoral neuroma were reported as the consequences of $\mathrm{FGM} / \mathrm{C}$, and prevalence rises increasingly from type to type [7]. Deliveries among women, who have undergone $\mathrm{FGM} / \mathrm{C}$ are significantly more associated with caesarean section, resuscitation of the infant, postpartum hemorrhage, episiotomy, inpatient perinatal death, and extended maternal hospital stays, compared to the uncircumcised women [8]. The study of Lax defined the psychological consequences of FGM/C as post-traumatic stress disorder, loss of trust, prevailing lack of physical wellbeing, shock and depressions [9].

Tradition, religion and social pressure seem to be the major motivation for performance of FGM/C [10]. The women or girls, who did not accept to go under procedure, were considered as acting against their religion and even against the Quran in some countries [11]. FGM/C is deeply rooted in the society, and its elimination definitely needs training, education and understanding the cultural perceptions and beliefs that feed it [12].

FGM/C may cause traumatic experience for women and girls, who have undergoing this procedure [13]. The FGM/C procedure is mostly remains a tremendously painful occurrence that impacts emotionally on the life of girls and women, so that they remember this experience as a psychological disturbance. This emotional disturbance may settle in their subconscious-mind and can lead to the disturbing behaviors [14]. The girls, who have gone under the procedure in the presence and assistance of their family members during the procedure, may lose their trust and confidence for their family members and confronted with severe psychological consequences [15]. According to the explanation of world health organization, the circumcised women may encounter with a large number of psychosomatic problems such as sleeping disorder, mood disorder, low selfesteem, chronic anxiety, depression, panic, phobia, and even psychotic disorders [16].

The study of Behrendt and Moritz indicated a higher prevalence of psychiatric syndromes, and posttraumatic stress disorder in FGM/C women compared to the noncircumcised women in Senegal [17].

The study of Hermlund and Shell-Duncan indicated that the circumcised women may suffer feelings of anxiety, incompleteness, chronic irritability, depression, and problematic relationship with their husbands [18]. A systematic review of the literature relating to the psychological problems of $\mathrm{FGM} / \mathrm{C}$, showed that there was a strong correlation between $\mathrm{FGM} / \mathrm{C}$ and suffering from emotional disorders, such as somatization, anxiety, low selfesteem, and to be at the great risk of a mental illness [19]. Such findings were reported by Chibber et al. too [20]. However, a study reported no differences in mental health among $\mathrm{FGM} / \mathrm{C}$ and non-circumcised women. in Bedouin [21].

Taking into consideration the findings of studies related to the impacts of $\mathrm{FGM} / \mathrm{C}$ on the psychological status of circumcised women, the healthcare professionals should pay great attention on the psychological status of circumcised women so that these women can cope with the negative psychological consequences of the procedure.

There is a great need to determine the effects of FGM/C on the psychological wellbeing of the Iranian Kurdish women, who live in Kurdistan province of Iran and compare them with uncircumcised women in the region, for preventing women from unhealthy and brutality procedures of circumcision.

Kurdistan Province is situated in the west of Iran. It is a mountainous region with mild climate during spring and summer, the winters are very cold and snowy. According to National Census, the inhabitants of Kurdistan were 1,603,000 in 2016. The majority of Kurdish people are Sunni Muslims, and their main activities are agriculture and farming [22]. The objective of current study was to compare the mental health status of circumcised women with the noncircumcised women in Kurdistan province of Iran.

\section{Methods}

This current comparative study was conducted in Kurdistan province of Iran to explore the impact of FGM/C on mental health of circumcised women living in Kurdistan and compare them with non-circumcised women. The Kurdistan province is about $28,817 \mathrm{~km}^{2}$ in the region that located in the west of Iran, it is bound by Iraq on the west, the province of west Azerbaijan in the north, Zanjan province in the northeast, Hamedan province to the east and Kermanshah province in the south. The capital city of Kurdistan province is Sanandaj.

The studied population in this current study consisted of 208 married women living in the Kurdistan Province of Iran, $104(50 \%)$ of them were circumcised women and $104(50 \%)$ of them were non-circumcised. Estimation of population size was measured at least 208 women (104 for each group) for analysis by utilizing the statistical software package of GPower. G-Power is a powerful statistical analysis program.

The women who referred to the health-care centers of Kurdistan province for vaccination, midwifery, family planning and consultations were interviewed. The purpose of study and procedure stages was clearly explained with emphasizing on protecting the privacy of personal 
information. Written satisfaction declarations of participants were obtained from those, who agreed to participate in the study.

The Persian translation of GHQ-28 questionnaire was used to gather data. Goldberg and Blackwell invented the GHQ-28 questionnaire and planned to identify psychological disorders in different centers and environments [23]. The GHQ-28 (General Health Questionnaire) measures the mental situation of persons in the last month. It consists of signs such as, normal emotions, thoughts and some facets of behaviors. GHQ-28 has been developed for screening and detecting the psychiatric disorders of individuals. It measures the health dimensions, such as: insomnia; anxiety; severe depression and social dysfunctions [24]. The reliability of Persian translation of GHQ-28 was verified by a study conducted in Tehran University of Medical Sciences. The study indicated that the Persian version of GHQ-28 can be used as a screening instrument for epidemiological study of mental disorders [25].

Since the majority of participated women in the study were uneducated; therefore, the research assistant explained the items of questionnaire in Kurdish language and completed them.

The gathered data was analyzed by soft-ware package of SPSS version 23. The independent $t$ - test was utilized between two groups of women (circumcised and noncircumcised women). The significant level was determined as $(P<0.05)$.

\section{Results}

The socio-demographic characteristics of participants are shown in table 1 . The mean age of circumcised-women was $27.9 \pm 5.61$ (ranging from 14-38 years). The mean of their marriage-age was $(20.1 \pm 3.33$ years $)$. The majority of circumcised-women, who participated in the study were either illiterate or had only the primary-education (64.4\%). Only $6(5.8 \%)$ of them were employed. The majority of circumcised women $78(75 \%)$ were living in the rural areas, and only $26(25 \%)$ of them were living in the Urban.

It is remarkable that there was a significant association between $\mathrm{FGM} / \mathrm{C}$ and education and also the attitudes of women with low educational background towards FGM/C. In other words, the more the education level of parents, the less their intensity to take their children towards $\mathrm{FGM} / \mathrm{C}$. It is obvious that the children begin to socialize in the family, where she/he learns the life skills; therefore, the education level of parents can play very important role for transferring the knowledge and attitude to the children through social learning [26]. The result of current study indicated that only $1.4 \%$ of circumcised women's mothers had middle school education, whereas $90.7 \%$ of them were either illiterate or had only primary school education. As a matter of fact, the women with low levels of education had further positive intensity taking their children towards $\mathrm{FGM} / \mathrm{C}$, as compared to the women with high level of education.

Table 1. Socio-demographic description of the participated women.

\begin{tabular}{|c|c|c|c|}
\hline Variables & Circumcised women $(n=104)$ & Non-circumcised women $(n=104)$ & p-value \\
\hline Age (years) & $27.9 \pm 5.61$ & $27.1 \pm 4.26$ & $0.000^{*}$ \\
\hline Age at Marriage (year) & $20.1 \pm 3.33$ & $22.4 \pm 4.00$ & $0.000^{*}$ \\
\hline Number of children & $1.56 \pm 0.95$ & $0.76 \pm 0.83$ & $0.000 *$ \\
\hline \multicolumn{4}{|l|}{ Education level } \\
\hline No education/primary school & $67(64.4 \%)$ & $46(44.2 \%)$ & $0.031^{*}$ \\
\hline Secondary school & $19(18.3 \%)$ & $26(25.0 \%)$ & \\
\hline Higher education & $18(17.3 \%)$ & $32(30.8 \%)$ & \\
\hline \multicolumn{4}{|l|}{ Father education } \\
\hline No education/primary school & $96(92.3 \%)$ & $79(76 \%)$ & $0.000 *$ \\
\hline Secondary school & $2(1.9 \%)$ & $8(7.7 \%)$ & \\
\hline Higher education & $6(5.8 \%)$ & $17(16.3 \%)$ & \\
\hline \multicolumn{4}{|l|}{ Mother education } \\
\hline No education/primary school & $101(97.1 \%)$ & $80(76.9 \%)$ & $0.000^{*}$ \\
\hline Secondary school & $2(1.9 \%)$ & $11(10.6 \%)$ & \\
\hline Higher education & $1(1 \%)$ & $13(12.5 \%)$ & \\
\hline \multicolumn{4}{|l|}{ Work status } \\
\hline Housewife & $98(94.2 \%)$ & $78(75 \%)$ & $0.000^{*}$ \\
\hline Employed & $6(5.8 \%)$ & $26(25 \%)$ & \\
\hline \multicolumn{4}{|l|}{ Source of income } \\
\hline Job, social benefit & $19(18.3 \%)$ & $36(34.6 \%)$ & 0.933 \\
\hline No independent income & $85(81.7 \%)$ & $68(65.4 \%)$ & \\
\hline \multicolumn{4}{|l|}{ Residential area } \\
\hline Rural & $78(75 \%)$ & $62(59.6 \%)$ & 0.139 \\
\hline Urban & $26(25 \%)$ & $42(40.4 \%)$ & \\
\hline
\end{tabular}

*p-Value is significant at less than 0.05 levels.

Regarding to the FGM/C action, $62.5 \%$ of $\mathrm{FGM} / \mathrm{C}$ has been accomplished before 3 years of their age. It is clear that the age, the girls gone under FGM/C differs from country to countries and even from region to region inside the same country. Sometimes the procedure is performed soon after birth [27]. The chief reasons for performing $\mathrm{FGM} / \mathrm{C}$, which announced by the circumcised-women were: Religious-reason (42.3\%), tradition (26\%), Cleanness 
(17.3\%), Sexual desire control (9.6\%) and Virginity (4.8\%) (Table 2). This is in agreement with the finding of TagEldin et al. [28], which found that one of the main factors for $\mathrm{FGM} / \mathrm{C}$ was religion belief $(33.9 \%)$. The reason of cleanliness for FGM/C included only $(8.9 \%)$, whereas the reason of social and cultural tradition consisted $17.9 \%$ and $15.9 \%$ respectively. This finding contradicts with the observation of Robinson, who found, the main reason of FGM/C was a social belief rather than religious belief [29]. According to knowledge, there is not any indication for FGM/C in Quran to support the FGM/C, in reverse Quran clearly condemns any kind of damaging the human body. Furthermore, there is no theological evidence in the religion to support the FGM/C [30]. The study moreover showed that the majority of circumcision-procedures were accomplished by the local circumcisers (70\%) without using any anesthetic drugs. Such findings were also reported by other study [31].

Table 2. Description of FGM/C procedures.

\begin{tabular}{ll}
\hline Variable & Value (n=104) \\
\hline Age of FGM & $65(62.5 \%)$ \\
$<3$ years & $26(25 \%)$ \\
$4-7$ years & $11(10.6 \%)$ \\
$8-11$ years & $2(1.9 \%)$ \\
$>12$ years & \\
Motivation for FGM & $44(42.3 \%)$ \\
Religion & $27(26 \%)$ \\
Tradition & $18(17.3 \%)$ \\
Cleanness & $10(9.6 \%)$ \\
Sexual desire control & $5(4.8 \%)$ \\
Virginity & \\
Person performed it & $76(73.1 \%)$ \\
Traditional circumcisers & $19(18.3 \%)$ \\
Grandmother & $9(8.7 \%)$ \\
Neighbor women & \\
Who insisted on this practice & $36(34.6 \%)$ \\
Mother & $54(51.9 \%)$ \\
Grandma & $14(13.5 \%)$ \\
Others & $83(79.8 \%)$ \\
Device & $14(13.5 \%)$ \\
Blade & $7(6.7 \%)$ \\
Knife &
\end{tabular}

Regarding to the information of Table 3 , highest score for both groups was for social-dysfunction $(7.53 \pm 1.97)$ in circumcised-women and $(7.40 \pm 4.09)$ in non-circumcised women. The mean score of general health for noncircumcised women was higher than the circumcised women. In other words, the non-circumcised women were in better status than circumcised women regarding to the mental wellbeing.

The $\mathrm{t}$ - test indicated that there was significant difference between circumcised-women and non-circumcised-women in the items of social-dysfunction and total scores of mental health. Regarding this fact that low score indicated high status of mental health and considering the comparison of groups' averages, this indicated that non-circumcised women had better mental health (Table 3 ).

Table 3. Results from t-test analysis of comparing the means of two samples mental health.

\begin{tabular}{llll}
\hline Variable & Mean \pm SD & t & p-value \\
\hline $\begin{array}{l}\text { Physical symptom } \\
\text { FGM/C }\end{array}$ & $6.99 \pm 0.17$ & & 0.70 \\
$\begin{array}{l}\text { Non-FGM/C } \\
\text { Sleep disorder }\end{array}$ & $5.71 \pm 2.71$ & & \\
$\begin{array}{l}\text { FGM/C } \\
\text { Non-FGM/C }\end{array}$ & $7.01 \pm 0.31$ & 1.585 & 0.504 \\
$\begin{array}{l}\text { Dysfunction } \\
\text { FGM/C }\end{array}$ & $5.08 \pm 3.18$ & & \\
$\begin{array}{l}\text { Non-FGM/C } \\
\text { Depression }\end{array}$ & $6.97 \pm 0.32$ & -0.353 & $0.000^{*}$ \\
$\begin{array}{l}\text { FGM/C } \\
\text { Non-FGM/C }\end{array}$ & $6.11 \pm 3.33$ & & \\
Total & $5.89 \pm 2.47$ & -1.719 & 0.886 \\
FGM/C & $4.62 \pm 1.26$ & & \\
Non-FGM/C & $26.8 \pm 2.52$ & & 0.015 \\
\hline
\end{tabular}

*p-Value is significant at less than 0.05 levels.

\section{Discussion}

Analysis of data showed that the mean age of circumcised women was $27.9 \pm 5.61$ (ranging from 14-38) years. The mean age of marriage for them was $20.1 \pm 3.33$ years; whereas the mean age of marriage for non-circumcised women was $22.4 \pm 4.00$. The majority of participants $(75 \%)$ were living in rural areas and only $25 \%$ of them were living in urban areas. $64.4 \%$ of the circumcised women were either illiterate or had only primary school education. This is an indicator that uneducated women are at high risk of FGM/C and they marry sooner than uncircumcised women. Education is a main indicator for protecting women against $\mathrm{FGM} / \mathrm{C}$; therefore, the human rights agencies and policy makers should improve the knowledge and awareness of women about the consequences of FGM/C by providing the facilities of education for girls in the area.

The study in addition indicated that there was a significant difference between circumcised-women and non-circumcised women in the term of social-dysfunction and total scores of mental health (Table 3 ). Considering the average scores of mental health between two groups, we found that noncircumcised women had higher mental health status compared to the non-circumcised women. Regarding to the social dysfunction the study indicated that there was considerable difference between two groups, however many factors may have influenced on this difference. The majority of FGM/C women were living in the rural and they were mainly uneducated or had only the primary level of education. In addition, there was significant difference between the education levels of the families in which they have been grown up. Even though we do not claim that the $\mathrm{FGM} / \mathrm{C}$ is an independent predictor of social dysfunction on the GHQ, or it is the chief factor that has influenced on the total scores of GHQ-28 in circumcised-women, but it is clear that the non-circumcised women were in better status 
compared to the circumcised women regarding to the social dysfunction as well as general health situation.

The findings of our study were consistent with the finding of Elsadavi [32] who found, FGM/C has negative effects on women's' physical and mental health, and it may affect sexual shocks on girls. Furthermore, FGM/C reduces the women's potential of reaching a full and enjoyable orgasm. She also found that FGM/C did not help to decrease the genital organs cancers. According to the reports of United Nations International Children's Emergency Fund (UNICEF), the $\mathrm{FGM} / \mathrm{C}$ violates the women basic rights and damages their health [33].

The findings of this current study were in consistence with the findings of Hermund and Shell Duncan who found that circumcised women may suffer from feeling incomplete, extreme dizziness, shattered aspirations, inability to function, and worrying about their FGM/C status [18]. In addition, the study of Dorkenoo indicated that circumcised women expressed many emotional and/or psychosocial problems, was in agreement with results of our study [34]. It is remarkable that all circumcised women in the study were verified as type I, which is the simplest form of circumcision.

\section{Conclusions}

The female genital mutilation / cutting (FGM/C) is an unpleasant procedure that disturbs the sexual satisfaction of women and may expose them to psychological and physical problems. The lack of education, knowledge and also lack of awareness about the consequences of $\mathrm{FGM} / \mathrm{C}$ are the main reason of family exposing their daughters against torture and inhumanity procedures.

Limitation of the study

The study has some limitations; first there is no exact information about the number of circumcised women in the area; therefore, we couldn't take all circumcised women under consideration. Second women had fear to participate in the study. Some of them believed that talking about FGM/C is shameful. The majority of women in the area were uneducated; therefore, the research assistant had to explain the items of questionnaire to them in Kurdish language for completing the forms. Third we compared the GHQ scores between tow limited groups of circumcised and non-circumcised women, to make clear that $\mathrm{FGM} / \mathrm{C}$ was an independent predictor of "social dysfunction" on the GHQ. We needed to do a longitudinal study for measuring the score of GHQ before FGM/C and also after $\mathrm{FGM} / \mathrm{C}$, but due to the limitation of time and money we couldn't do it.

Conflict of Interest: The authors declare that they have no conflict of interest.

Statement of human rights: This current study has been approved by the ethics committee of Tabriz University of Medical Sciences, and has been performed in accordance with the ethical standards as laid down in the 1964 Declaration of Helsinki and its later amendments or comparable ethical standards.
Informed consent: All participants gave informed consent to their involvement in this study.

Ethical approval

The ethical committee of research affairs of Tabriz University of Medical Sciences has approved the current study.

\section{Authors' contribution}

All authors contributed to this work.

Mohammad-Hossein Biglu, designed the study, interpreted the data and wrote the paper.

Alireza Farnam participated in developing the design and interpreting of analyzed data.

Parvaneh Abotalebi, participated in gathering the data, and conducting the literature reviewing of study.

Acknowledgments

The authors would like to thanks all people who participated in the current study

\section{References}

[1] Biglu M-H, Farnam A, Abotalebi P, Biglu S, Ghavami M. Effect of female genital mutilation/cutting on sexual functions. Sexual \& Reproductive Healthcare. 2016.

[2] Caroppo E, Almadori A, Giannuzzi V, Brogna P, Diodati A, Bria P. Health care for immigrant women in Italy: are we really ready? A survey on knowledge about female genital mutilation. Annali dell'Istituto Superiore di Sanità. 2014; 50 (1): 49-53.

[3] Organization WH, UNICEF. Female genital mutilation: a joint WHO/UNICEF/UNFPA statement. World Health Organization; 1997.

[4] Organization WH. Female genital mutilation: report of a WHO technical working group, Geneva, 17-19 July 1995. 1996.

[5] Wadesango N, Rembe S, Chabaya O. Violation of women's rights by harmful traditional practices. Anthropologist. 2011; 13 (2): 121-129.

[6] Mandara MU. Female genital mutilation in Nigeria. International Journal of Gynecology \& Obstetrics. 2004; 84 (3): 291-298.

[7] Ceesay H. Female genital mutilation/cutting in The Gambia: long-term health consequences and complications during delivery and for the newborn. International journal of women's health. 2013; 5: 323-331.

[8] WHO. Female genital mutilation and obstetric outcome: WHO collaborative prospective study in six African countries. The Lancet. 2006; 367 (9525): 1835-1841.

[9] Lax RF. Socially sanctioned violence against women: Female genital mutilation is its most brutal form. Clinical Social Work Journal. 2000; 28 (4): 403-412.

[10] Rahimi A, Ardalan A, Felah A, Majlessi F, Pashaei T. Related factors of female genital mutilation (FGM) in Ravansar (Iran). Journal of Womens Health Care. 2012; 2012.

[11] Berg RC, Denison E. A tradition in transition: factors perpetuating and hindering the continuance of female genital mutilation/cutting (FGM/C) summarized in a systematic review. Health care for women international. 2013; 34 (10): 837-859. 
[12] Isman E, Mahmoud Warsame A, Johansson A, Fried S, Berggren V. Midwives' experiences in providing care and counselling to women with female genital mutilation (FGM) related problems. Obstetrics and gynecology international. $2013 ; 2013$

[13] Organization WH. An update on WHO's work on female genital mutilation (FGM): Progress report. 2011.

[14] Masterson JM, Swanson JH. Female genital cutting: breaking the silence enabling change. 2000.

[15] Hayes RO. Female genital mutilation, fertility control, women's roles, and the patrilineage in modern Sudan: a functional analysis. American Ethnologist. 1975; 2 (4): 617633.

[16] WHO. Female genital mutilation: Information kit. 1999.

[17] Behrendt A, Moritz S. Posttraumatic stress disorder and memory problems after female genital mutilation. American Journal of Psychiatry. 2005;162 (5): 1000-1002.

[18] Hernlund Y, Shell-Duncan B. Transcultural positions: negotiating rights and culture. Transcultural bodies: Female genital cutting in global context. 2007: 1-45.

[19] Berg RC, Denison EM-L, Fretheim A. Psychological, social and sexual consequences of female genital mutilation/cutting (FGM/C): a systematic review of quantitative studies. 2010.

[20] Chibber R, El-Saleh E, El Harmi J. Female circumcision: obstetrical and psychological sequelae continues unabated in the 21 st century. The Journal of Maternal-Fetal \& Neonatal Medicine. 2011; 24 (6): 833-836.

[21] Applebaum J, Cohen H, Matar M, Abu Rabia Y, Kaplan Z. Symptoms of posttraumatic stress disorder after ritual female genital surgery among Bedouin in Israel: Myth or reality. Primary care companion to the Journal of clinical psychiatry. 2008; 10 (6): 453-456.

[22] Kurdistan, Cardle of Iranian Civilization 2015; http://en.farsnews.com/print.aspx? nn=13931227000305.

[23] Goldberg DP. The detection of psychiatric illness by questionnaire: A technique for the identification and assessment of non-psychotic psychiatric illness. 1972.
[24] Jackson C. The general health questionnaire. Occupational medicine. 2007; 57 (1): 79-79.

[25] Noorbala, A. A., \& Mohammad, K. (2009). The validation of general health questionnaire-28 as a psychiatric screening tool. Hakim Research Journal, 11 (4), 47-53. Available at: http://www.sid.ir/fa/VEWSSID/J_pdf/57113870408.pdf

[26] Kandala N-B, Nwakeze N, Kandala SNI. Spatial distribution of female genital mutilation in Nigeria. The American journal of tropical medicine and hygiene. 2009; 81 (5): 784-792.

[27] Organization WH. Eliminating Female Genital Mutilation: An interagency statement-OHCHR, UNAIDS, UNDP, UNECA. UNESCO, UNFPA, UNHCR, UNICEF, UNIFEM, WHO, WHO, Geneva; 2008.

[28] Tag-Eldin MA, Gadallah MA, Al-Tayeb MN, Abdel-Aty M, Mansour E, Sallem M. Prevalence of female genital cutting among Egyptian girls. Bulletin of the World Health Organization. 2008; 86 (4): 269-274.

[29] Robinson B. Debates about FGM in Africa, the Middle East \& Far East. Religious Tolerance, http://www. religioustolerance. org/fem_cirm. htm. 1998.

[30] Jones SD, Ehiri J, Anyanwu E. Female genital mutilation in developing countries: an agenda for public health response. European Journal of Obstetrics \& Gynecology and Reproductive Biology. 2004; 116 (2): 144-151.

[31] Tag-Eldin MA, Gadallah MA, Al-Tayeb MN, Abdel-Aty M, Mansour E, Sallem M. Prevalence of female genital cutting among Egyptian girls. Bulletin of the World Health Organization. 2008; 86 (4): 269-274.

[32] El Saadawi N. The hidden face of Eve: Women in the Arab world. Zed Books; 2007.

[33] UNICEF. Female genital mutilation/cutting: a statistical exploration 2005. UNICEF; 2005.

[34] Dorkenoo E. Cutting the rose: female genital mutilation: the practice and its prevention. 1994. 